\title{
Morphology and life cycle of a new species of Psilocladus Blanchard, 1846 (Coleoptera, Lampyridae, Psilocladinae), the first known bromeliad-inhabiting firefly
}

\author{
Stephanie Vaz ${ }^{1,2}$; Luiz Felipe Lima da Silveira ${ }^{2,3}$ \& Simone Policena Rosa ${ }^{4}$ \\ 1 Universidade Federal do Rio de Janeiro (UFRJ), Instituto de Biologia (IB), Departamento de Zoologia, Laboratório de Polychaeta. \\ Rio de Janeiro, RJ, Brasil. ORCID: http://orcid.org/0000-0002-2616-640X. E-mail: anievaz@gmail.com \\ 2 Universidade Federal do Rio de Janeiro (UFRJ), Instituto de Biologia (IB), Departamento de Ecologia, Laboratório de Ecologia de Insetos. \\ Rio de Janeiro, RJ, Brasil. \\ ${ }^{3}$ Western Carolina University, Dept. of Biology. Cullowhee, U.S.A. ORCID: http://orcid.org/0000-0002-0648-3993. E-mail: silveira.Ifl@gmail.com \\ ${ }^{4}$ Universidade Federal de Itajubá (UNIFEI), Instituto de Recursos Naturais (IRN). Itajubá, MG. Brasil. \\ ORCID: http://orcid.org/0000-0002-7499-9158. E-mail: simonepolicena@unifei.edu.br
}

\begin{abstract}
Fireflies (Coleoptera: Lampyridae) are soft-bodied beetles usually associated with mesic and hydric habitats. As such, terrestrial firefly larvae are commonly found in marshy environments and stream banks, while aquatic larvae might dwell in ponds, streams, mangroves, and even brackish water. Larval biology is especially important in fireflies, as the majority of species are extremely semelparous - that is, adults rely on resources gathered during larval stages. Despite their crucial relevance in firefly biology, larvae of only near $1 \%$ firefly species have been studied, and the majority of species remain known only from adult stages. That is especially true in the Neotropical region, where they are most diverse. Here, we describe Psilocladus costae sp. nov. after the study of adults and immature stages, the latter reported for the first time for the monotypic subfamily Psilocladinae McDermott, 1964. Interestingly, adults were first obtained by rearing the larvae, the former usually fly fairly high $(c a .10 \mathrm{~m})$ and are therefore seldom collected at ground level by conventional methods (e.g., active search, Malaise traps). The new species is found in the Brazilian Atlantic Rainforest, inhabiting canopy bromeliads, an unprecedented habit for fireflies.
\end{abstract}

Key-Words. Psilocladinae, Bromeliad, Immature beetles, Neotropical, Fireflies.

\section{INTRODUCTION}

There are over 2,000 firefly species (Coleoptera: Lampyridae) world-wide (Branham, 2010). The bioluminescent behavior of this charismatic group draws attention of people all around the globe (Faust, 2017). Some species gather in numbers and have attracted large audiences in various continents (e.g., Jeong et al., 2005; Faust, 2010), while others have been model systems for scientific studies, biotechnological innovations (e.g., Chen et al., 2015), and/or pest control (e.g., Fu \& Meyer-Rochow, 2013). Despite their charisma and economic value, knowledge about Neotropical fireflies is relatively incipient compared to other regions of the planet (e.g., Asia [Ballantyne et al., 2019]; North America [Faust, 2017]). Most Neotropical species are only known from century-old original taxonomic descriptions, which are virtually always restricted to adult males. Indeed, only near $1 \%$ of firefly species have been studied during their immature stages. However, immature stages are crucial parts of species' ecological niche, especially in fireflies, as most species do not feed as adults, and rely on resources gathered during the larval stage. Therefore, studies comprehensively addressing all life stages are sorely needed in the firefly literature.

In the Neotropical region, where fireflies are most diverse (Costa, 2000), the few species that have been studied have diverse life histories. Professor Cleide Costa and colleagues were the first to describe in detail firefly larvae in the Neotropical region, in a book that would set the standards for larval studies in beetles, the "Larvas de Coleoptera do Brasil" (Costa et al., 1988). Costa et al. (1988) compared the larval morphology of four firefly species, Lucio castelnaui Kirsch, Aspisoma sp., Cratomorphus sp. and Bicellonycha sp., all of which are terrestrial and found on the leaf litter and low vegetation. Later, three other species were found in similar habitats: Pyractonema nigripennis Solier 
(Archangelsky, 2010), Aspisoma lineatum (Viviani et al., 2012), and Photuris femoralis Curtis (Rosa, 2007; cf. Souto et al., 2019). Additionally, the larvae of Cratomorphus cossyphynus Perty (Campos et al., 2018), Aspisoma fenestrata Blanchard (Archangelsky, 2004), Aspisoma sp. (Viviani, 1989) and Aspisoma sticticum Gemminger (Matos, unpublished) are semi-aquatic (i.e. associated to water bodies, but lacking adaptations to breath under water) and live in ponds and marshes. Several genera endemic to the Neotropical region have no larval descriptions at all. Indeed, out of 36 genera occurring in South America, only 5 have any species where larvae are known, all in the subfamily Lampyrinae Rafinesque or Photurinae Lacordaire; larvae of Amydetinae Olivier and Psilocladinae McDermott remain unknown. Here, we describe Psilocladus costae sp. nov. after the study of adults and immature stages, the latter reported for the first time for the monotypic subfamily Psilocladinae sensu Martin et al. (2019).

The genus Psilocladus Blanchard, 1842 comprised 42 species distributed in the Neotropical region, of which 11 were recorded for Brazil (McDermott, 1966). Psilocladus costae sp. nov. is found in the Brazilian Atlantic Rainforest (South America), inhabiting bromeliads during the larval stage, an unprecedented habit for fireflies. This new species is named in honor of Professor Cleide Costa (MZSP), who fostered this study directly and indirectly, as she supervised S. Rosa, who tutored L. Silveira during his studies, and the latter mentored S. Vaz in her studies. Professor Cleide Costa continuously inspires us in the study of bioluminescent Coleoptera.

\section{MATERIAL AND METHODS}

We collected larvae and adults from May 2017 to October 2019, in a legal reserve at Campos do Jordão (São Paulo State, Brazil, Global Positioning System $22^{\circ} 40^{\prime} 51.3^{\prime \prime} \mathrm{S}, 45^{\circ} 35^{\prime} 30.6^{\prime \prime} \mathrm{W}$ ) (Figs. 1A-D), which is close to Parque Estadual de Campos do Jordão, covering 503 ha of Atlantic Rainforest in different conservation levels. During the day, we collected the larvae in leaf sheaths of fallen epiphytic bromeliads Vriesea betuminosa Wawra (Bromeliaceae) following the protocol described in Biffi \& Rosa (2019). During the night, we collected larvae and adults, both them localized outside bromeliads by their bioluminescence (Figs. 2A-C). In addition to these adults, we studied material available in the following institutions (curator in parenthesis): CLEl, Coleção entomológica do Laboratório de Ecologia de Insetos, Universidade Federal do Rio de Janeiro, Brazil (M. Macedo); Universidade Federal de Itajubá, Brazil (UNIFEI); MNHN, Muséum National d'Histoire Naturelle, France (A. Taghavian) and MZSP, Museu de Zoologia da Universidade de São Paulo, Brazil. In total, we examined 11 adult specimens of Psilocladus costae sp. nov. (two females and nine males), one pupa and 18 larvae. We dissected three males, one female and three larvae. Immatures are deposited at CLEl and UNIFEI.

We reared the larvae at Laboratório de Zoologia (UNIFEI), at ambient temperature of Itajubá municipality, Minas Gerais state, with climate normal temperatures of $15,1^{\circ} \mathrm{C}-19,50^{\circ} \mathrm{C}$ in autumn-winter, and $20,5^{\circ} \mathrm{C}-22,2^{\circ} \mathrm{C}$ in spring-summer, which are approximately $5^{\circ} \mathrm{C}$ warmer than temperatures in Campos do Jordão in the same period (INMET, 2019). Larvae were individually kept in $80 \mathrm{ml}$ capped plastic pots with sand in the bottom and 2-3 small pieces of bromeliad leaf above the sand. The substrate was kept very wet to mimic the environment, as much as the innermost leaf sheath of bromeliads where most larvae were found (Fig. 2C). Larvae were fed weekly with termite workers and scirtid (Coleoptera) larvae, the latter collected in the same bromeliads we found lampyrid larvae. Dead larvae that quickly decomposed were not preserved. The material examined included dead larvae in good condition, and larvae and pupae killed and fixed in boiling water. Immatures and adults were preserved in $70 \%$ ethanol following Costa et al. (1988) and $90 \%$ ethanol following Campos et al. (2018). Adults and larvae were left 24 hours in a $\mathrm{KOH}$ solution at $10 \%$ before examination, then dissected with scissors and fine-tipped tweezers. Photos were acquired by a multifocal photographic system LEICA M205C, using LEICA V4 application suite and a Canon Rebel T6. Drawings were made under a stereomicroscope coupled to a camera lucida. For morphological terminology, we followed Beutel (1995) and Branham (2010) for immature stages, and Silveira \& Mermudes (2014) for adults.

For the sake of convenience, we compare the new species to the three other species of Psilocladus found in Southeastern Brazil (a region that comprises four states: Espírito Santo, Minas Gerais, Rio de Janeiro and São Paulo): P. grandis Olivier, 1888; P. pulcher Olivier, 1885; and P. sigillatus Olivier, 1907.

\section{RESULTS}

\section{Taxonomy}

Psilocladinae McDermott, 1964 sensu Martin et al. (2019) Psilocladus Blanchard, 1846

Type species: Psilocladus miltoderus Blanchard, 1846, by monotypy.

\section{Key to males of Psilocladus species in Southeastern Brazil}

1 Sterna VI and VII lacking lanterns (Rio de Janeiro, Minas Gerais, São Paulo) Psilocladus sigillatus Olivier, 1907

$1^{\prime} \quad$ Sterna VI and VII bearing lanterns.

2 Sternum VI with lanterns as two rounded spots (Rio de Janeiro) Psilocladus grandis Olivier, 1888

$2^{\prime}$ Sternum VI with lanterns entire.

3 Pronotum with sides almost straight, yellow with a black to dark-brown Iongitudinal stripe on median region (Rio de Janeiro) Psilocladus pulcher Olivier, 1885

3' Pronotum with sides divergent posteriad, entirely yellow, without a black to dark-brown longitudinal stripe (São Paulo) Psilocladus costae sp. nov. 


\section{Psilocladus costae sp. nov.}

(Figs. 3-14)

Type material: HOLOTYPE $0^{\top}$ (CLEI): BRAZIL. São Paulo: Campos do Jordão, 2240'51.3", 453'30.6", 1464 mm, 02.VII.2017, S. Rosa \& Ladenthin leg. PARATYPES. Same locality of holotype, 23.XII.2016, S. Rosa \& Ladenthin (3 o", CLEI); (collected as larva on 02.VII.2017, adult on 04.XII.2017), S. Rosa \& Ladenthin leg (1 $\sigma^{\prime \prime}$, CLEI); 02.XII.2017, Rosa, S \& Ladenthin leg (1 ox, CLEI); 08-10. XII.2017, S. Rosa \& Ladenthin (3 o', MZSP); 18-20.I.2018, S. Rosa leg (1 $\sigma^{7}$, CLEI); 08-13.II.2018, S. Rosa leg (1 \&, CLEI).

Additional material examined: BRAZIL. São Paulo: Vale do Rio Pardo, XII.1998, Gounelle, E. (1 \&, MNHN); Campos do Jordão, 2240'51.3", 45³5'30.6", 1,464 m (collected as larva on 05.VII.2018, pupa on 17.XII.2018), S. Rosa leg. (1 pupa, CLEI); 27.V.2017, S. Rosa leg. (2 larvae, CLEI); 09.XI.2017, S Rosa leg. (1 larva, UNIFEI);04.XII.2017, S. Rosa leg. (1 larva, UNIFEI); 22.III.2018, S. Rosa leg. (1 larva, CLEI); 25.III.2018, S Rosa leg. (1 larva, 1 larval exuvia, UNIFEI); 05.V.2018, S. Rosa leg. (1 larva, UNIFEI); 24.VI.2018, S. Rosa leg. (1 larva, UNIFEI); 30.VI.2018, S. Rosa leg. (2 larvae, UNIFEI); 16.VII.2018, S. Rosa leg. (2 larvae, CLEI); 27.VIII.2018, S. Rosa leg. (1 larva, CLEI); 17.IX.2018, S. Rosa leg. (2 larvae, CLEI); 08.III.2019, S. Rosa leg. (2 larvae, CLEI); 27.X.2019, S. Rosa leg. (1 larva, UNIFEI).

\section{Adult}

Diagnosis (Figs. 3-9): Antennae with 11 antennomeres, biflabellate, covered by dense, upright bristles, males with flabellae twice longer than antennomere body length, basally attached and decreasing in length towards antennal apex. Antennal sockets large, as wide as $1 / 3$ frontal width. Apical maxillary and labial palpomeres securiform. Pronotum semilunar, outlined by deep punctures.

Male: Sternum VI with light organ as long as $3 / 4$ sternum length and as wide as $1 / 2$ sternum width. Sternum VII with light organ as long as $2 / 3$ sternum length and as wide as sternum width. Sternum VIII with posterior margin slightly emarginate; syntergite robust, slightly longer than sternum IX with anterior margin emarginate; phallus with dorsal and ventral plates; dorsal plate basally fused to parameres, slightly smaller than parameres, struts pro- jected toward phallobase; parameres symmetric, apically acute; phallobase symmetric, with posterior margin rounded and lateral margins emarginate.

Female: Sternum VII with light organ almost as wide as sternum width, with anterior and posterior margins slightly emarginate.

Color pattern: Frons, antennae and mouthparts dark brown (Figs. 3B-C, 4A-D); pronotum orange (Figs. 5A-E); scutellum light brown (Fig. 5F); elytra black with lateral margins light brown (Figs. 6D-F); pro and mesocoxae entirely orange; trochanter orange; femur, tibia and tarsus dark brown (Figs. 6A-C); sterna II-V dark brown (Fig. 3C), sterna VI-VII with median region translucent (Fig. 3C), sternum VIII brown (Fig. 7A) and pygidium dark brown (Fig. 7B).

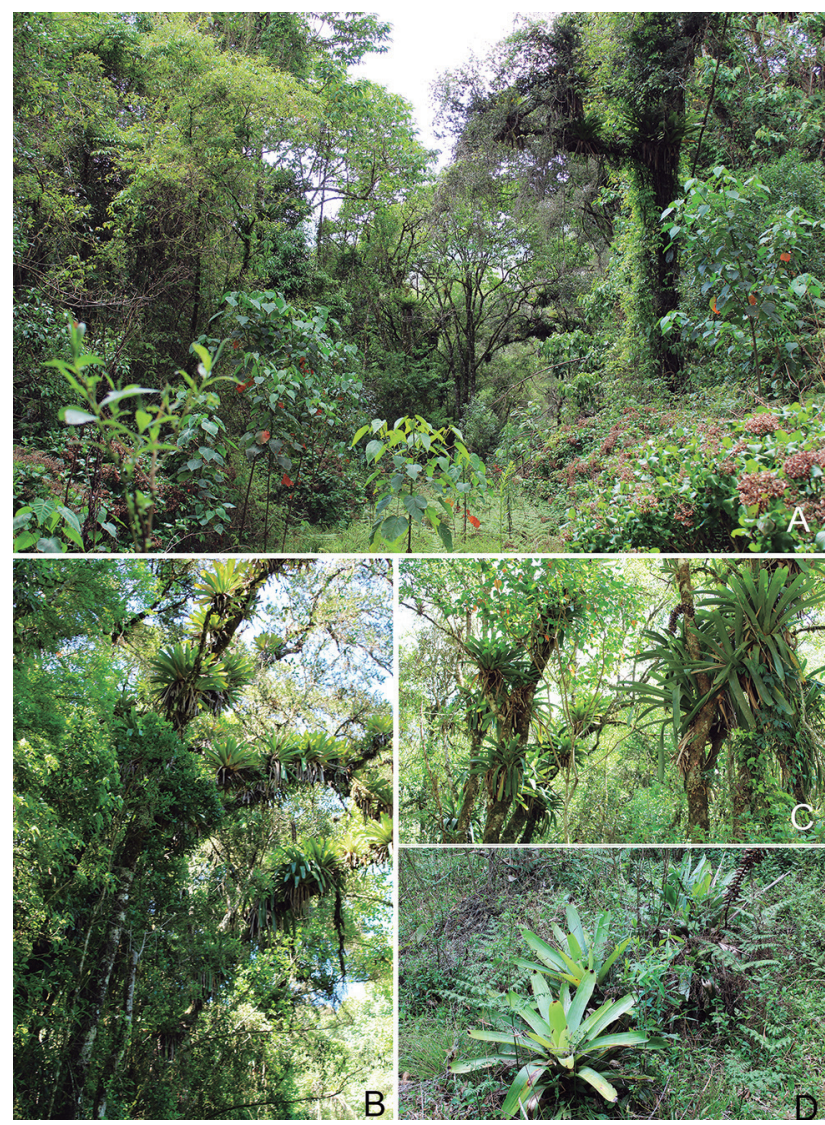

Figure 1. Psilocladus costae sp. nov. Habitat at Campos do Jordão, São Paulo. (A) Legal reserve along deforested area; $(B, C)$ canopy bromeliads; (D) fallen bromeliads Vriesea bituminosa.

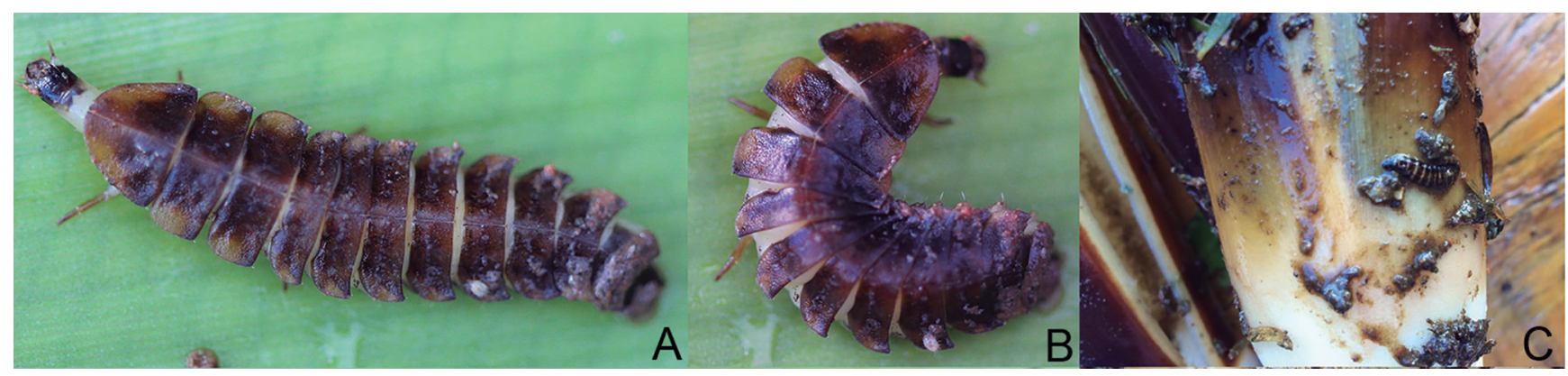

Figure 2. Psilocladus costae sp. nov. Live larvae. (A, B) Larva on bromeliad leaf blades (dorsal); (C) larva on a detached innermost leaf sheath of bromeliad rosette. Length of larva: $20 \mathrm{~mm}$. 
Head (Figs. 3-4) entirely covered by pronotum (Figs. 3A-C); almost $2 \times$ wider than tall (Fig. 4D); lateral margins slightly convergent posteriad (Figs. 4B, E, F). Frons slightly emarginate (Fig. 4D). Antennal sockets reniform, $1 / 2$ as wide as frons (Figs. 4A, C, D); vertex convex (Figs. 4E-F). Antennae with 11 antennomeres, covered by dense, upright bristles, scape robust apically, pedicel almost as long as wide, antennomeres III-X biflabellate, cylindrical, decreasing in length, apical antennomere as long as scape (Fig. 4G). Frontoclypeus slightly curved (Figs. 4A, D). Labrum connected to frontoclypeus by membrane (Fig. 4D). Mandibles stout basally, acute apically, with a basal fringe of bristles (Figs. 4A, D). Maxillae with cardo well-sclerotized; stipites rounded. Palpi 4-segmented: I short, trapezoidal with angles acute in relation to II, II rectangular $2 \times$ longer than III, III rounded, IV securiform, $1.5 \times$ longer than II and $2 \times$ wider than II narrowing towards apex. Labium with palpi 3-segmented, palpomeres I and II rectangular, slightly enlarged towards apex; III triangular and elongated, $2 \times$ longer than II. Gular sutures almost indistinct (Fig. 4B).

Thorax (Figs. 5-6). Pronotum semilunar, anterior margin rounded, lateral margins divergent, posterior margin with central region slightly projected posteriad and medially emarginate, posterior angles rounded, regularly punctured, punctures small and bristled (Figs. 5A-D). Hypomeron $2 \times$ longer than tall (Fig. 5E). Prosternum slightly constricted medially (Fig. 5B). Elytra ellipsoid, 4X longer than wide at greatest width, secondary pubescence absent (Figs. 6D-F). Hind wing well-developed, posterior margin sinuose, $2 \times$ longer than wide, $r 4$ almost $3 \times$ longer than $r 3$, radial cell $3 \times$ wider than long, almost reaching anterior margin; CuA2 cross vein absent; MP3 + 4 Y-shaped and basally connected with $\mathrm{Cu}$; $\mathrm{RP}+\mathrm{MP} 1+2$ of three fourths $\mathrm{r} 4$ length, almost reaching distal margin; AA3 parallel with CuP + AA3; CuA truncate in the origin (Fig. 6G). Alinotum slightly wider than long, lateral margins slightly convergent posteriad, posterior margin straight; prescutum extending slightly less than half metascutum length; rounded area of scutum weakly sclerotized, scutum-prescutal plates sclerotized, extending ridges almost up to posterior margin; metascutellum glabrous. Mesosternum weakly sclerotized, acute medially, attached to metasternum by a suture, almost as wide as mesosternum. Mesepimeron attached to metasternum by membrane. Mesosternum/mesanepisternum suture inconspicuous. Mesanepisternum/mesepimeron suture conspicuous. Metasternum oblique and strongly depressed by mesocoxae, anterior medial keel prominent up to anterior third, discrimen distinct, lateral margins divergent posteriad up to lateral-most part of metacoxae, then convergent posteriad, posterior margin bisinuose (Figs. 5F-I). Femur slightly shorter than tibia (Figs. 6A-C). Tarsomere I $2 \times$ longer than II, II slightly longer than III, III subequal in length to IV, IV bilobed, lobes reaching half $\mathrm{V}$ length (Figs. $6 \mathrm{~A}-\mathrm{C}$ ).

Abdomen (Fig. 7): Seven visible sterna (II-VIII) (Fig. 3C), lateral margins convergent posteriad, spiracles dorsal (i.e. dorsally reflexed margins of sternite) (Fig. 3B); sternum VIII $3 \times$ wider than long, posterior margin emarginate (Fig. 7A); pygidium sclerotized, anterior margin indented, lateral margins rounded and posterior margin with two parassagital sinuosities, lateral angles poorly developed (Fig. 7B); syntergite subtriangular, subdivided and with
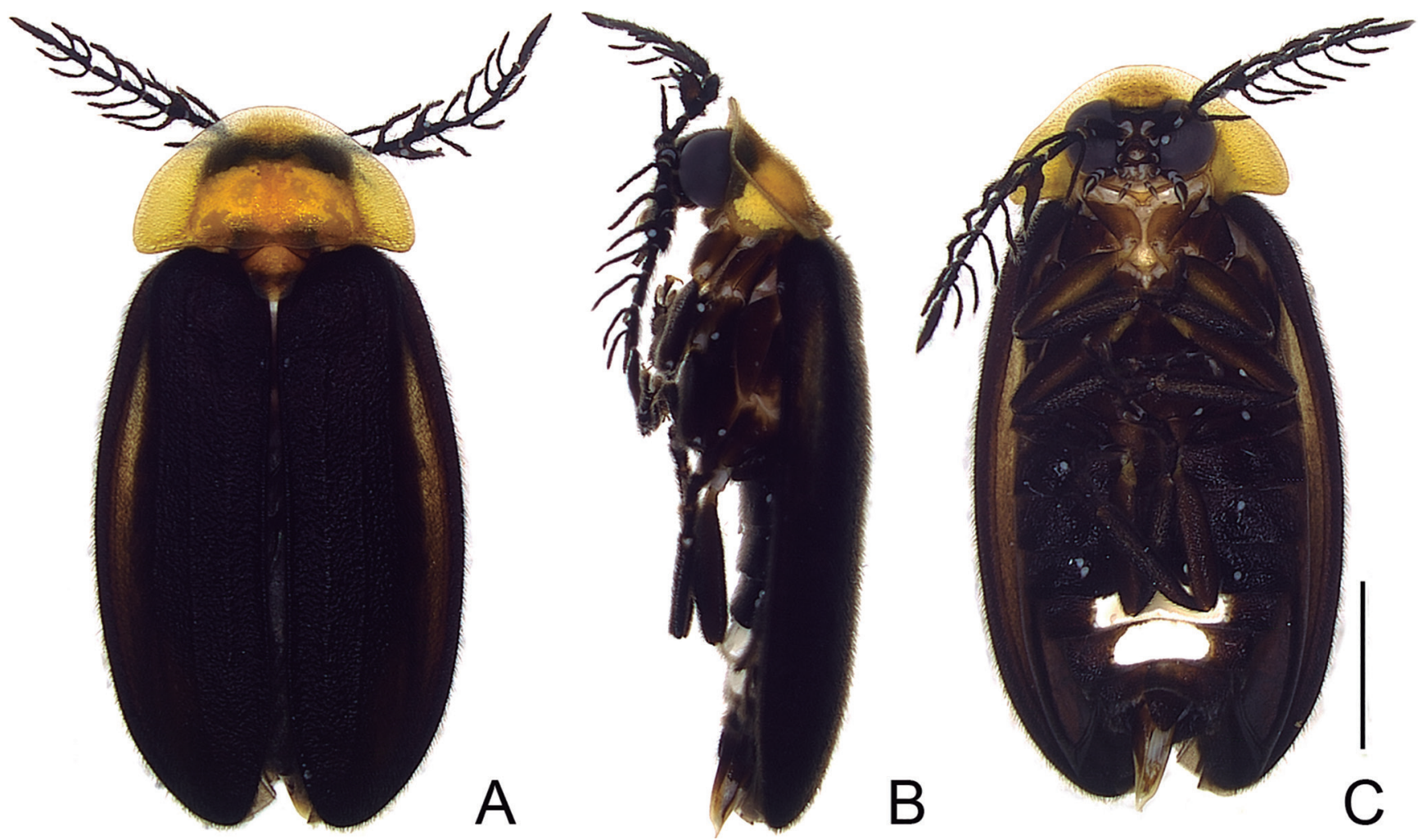

Figure 3. Psilocladus costae sp. nov. Adult male habitus. (A) Dorsal; (B) lateral; (C) ventral. Scale bar: $=2 \mathrm{~mm}$. 
anterior margin emarginate (Fig. 7C); sternum IX with posterior margin convergent posteriad, posterior margin rounded, with a spine in central region of the anterior margin (Fig. 7D). Aedeagus (Figs. 7E-G): Phallobase symmetrical, with a distinct longitudinal line (Figs. 7E, G); parameres symmetrical, connected basally by a thin bridge, apically acute, apical $1 / 2$ membranous, internal margin sinuose (Figs. 7E-G); phallus with struts almost straight, extending basally slightly beyond parameres; ventral plate coriaceous, dorsal plate flat, apically acute, strongly sclerotized (Fig. 7G).

Female (Figs. 8, 9): Eye almost $2 / 3$ as wide as frons in frontal view (Figs. 8B, 9A-E); antennae with short flabellae which are slightly longer than core antennomere (Fig. 9F); pronotum $2 \times$ wider than long (Fig. $8 \mathrm{~A}$ ); sternum VI with subrectangular light organ (Fig. $8 \mathrm{~B}$ ) almost as wide as sternum width; sternum VII lacking light organ (Fig. 8B); sternum VIII with lateral margins converging posteriad and posterior margin with central region emarginate (Fig. 9G); pygidium with lateral margins convergent and posterior margin rounded (Fig. 9H). Genitalia: ovipositor with baculus sclerotized, coxites membranous, styli (pointed) apically sclerotized and bristled outwards at the lateral edges (Figs. 9l-J).

\section{Immature stages}

Mature larva (Figs. 10-12). Description: Body (Figs. 10A-C) 15-22 mm long, oblong (pronotum semio-
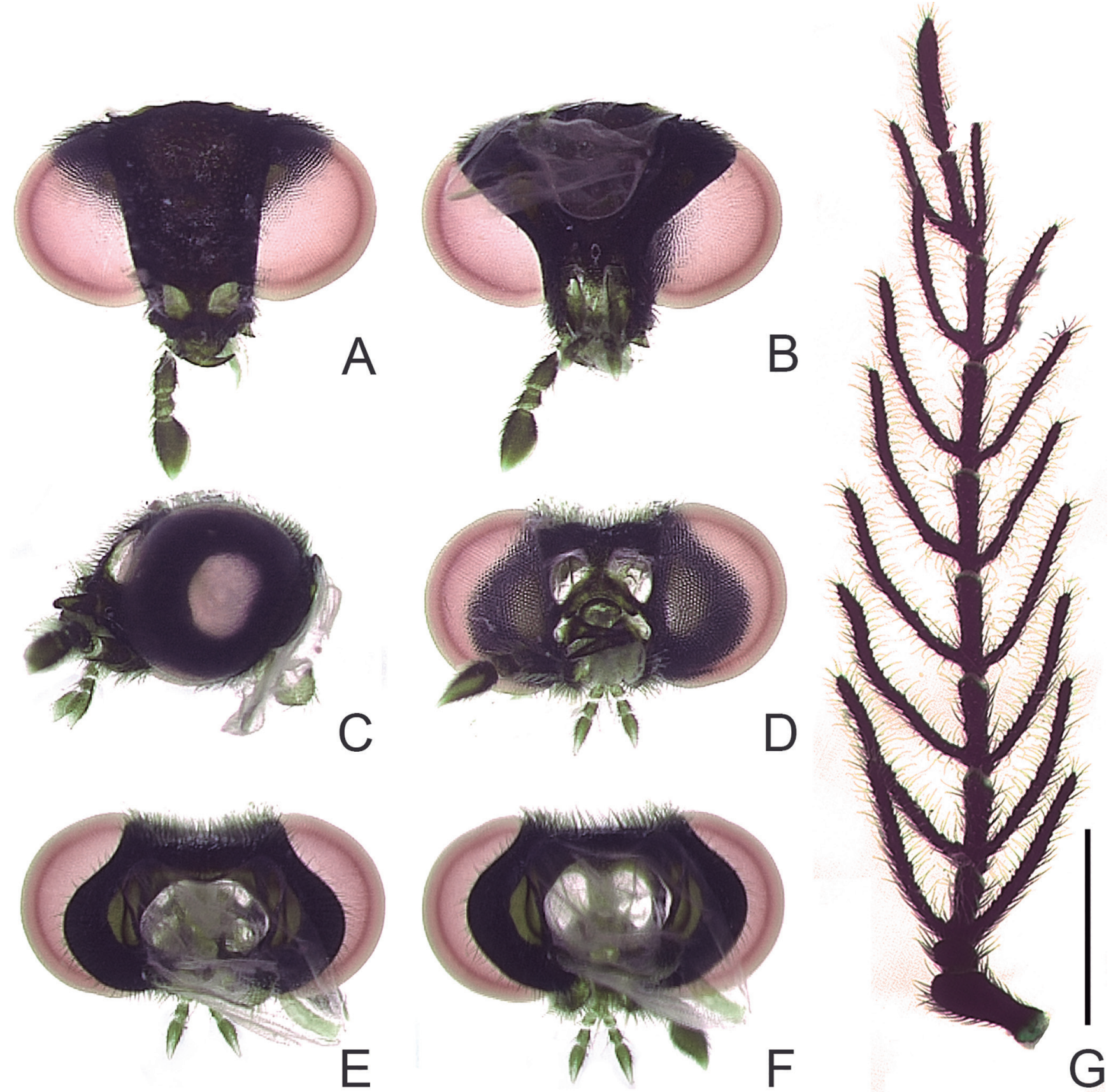

Figure 4. Psilocladus costae sp. nov. Head morphology of adult male. (A-F) Head; (A) dorsal; (B) ventral; (C) lateral; (D) frontal; (E) occipital; (F) posterior; (G) left antenna (dorsal). Scale bar: $=1 \mathrm{~mm}$. 

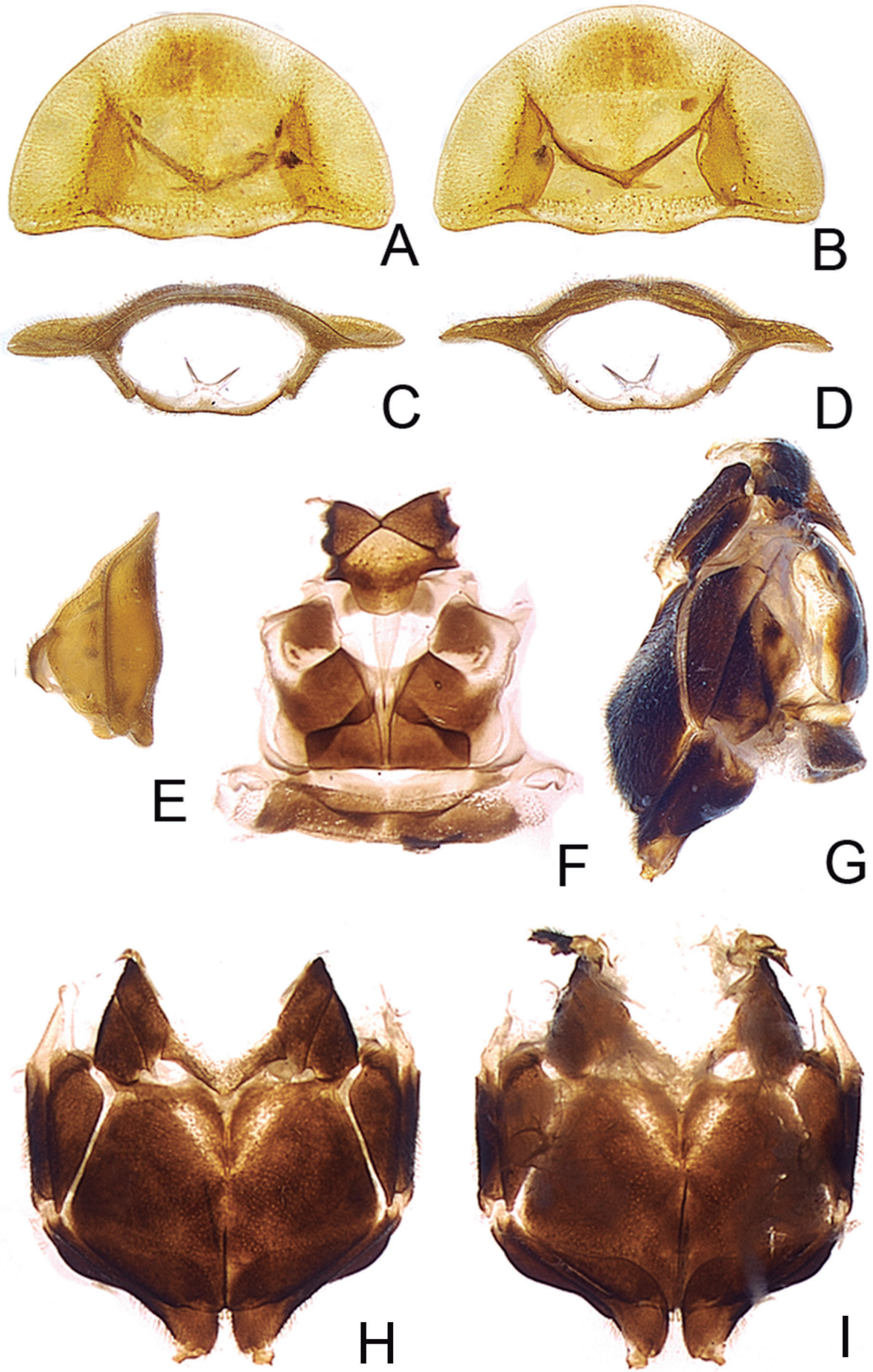

Figure 5. Psilocladus costae sp. nov. Thorax morphology of adult male. (A-E) Prothorax: (A) dorsal; (B) ventral; (C) frontal; (D) posterior; (E) lateral; (F-I) pterothorax, (F) dorsal; (G) lateral; (H) dorsoventral. Scale bar: $=2 \mathrm{~mm}$. 
val, widest at metathorax and gradually decreasing in width posteriorly from abdominal segment III), dorsoventrally flattened. Head dark brown, antennae, palpi and mandibles lighter (Figs. 11A-C); dorsal surface of body brown, with yellow spot on anterior $2 / 3$ of lateral margins of thorax and abdominal terga I-VI (Fig. 10A); terga VII-VIII with lateral vitreous spots (Fig. 11F). Tegument densely covered with short, very fine, grayish pubescence (Fig. 10B).

Head (Figs. 10B-C, 11A-C, 12A): As long as wide, almost entirely retractable into prothorax (Figs. 10B-C); dorsal surface with long, fine and sparse setae on anterior and lateral regions, one stemma with convex lens laterally at base of antennifer; antennifer membranous and glabrous, as long as basal antennomere (Figs. 12A, E). Frontal arms V-shaped, well impressed at posterior half, weakly impressed at anterior half, almost reaching base of antennifer (Fig. 12A); epicranial stem very short; clypeolabrum fused to frons, partly membranous, lateral part darkly sclerotized and bilobate, median part translucent, with dark fusiform plate at middle; fusiform plate with anterior part fused to cranium, forming acute tooth; posterior part fused to epipharynx and visible through translucent cuticle (Figs. 11A, 12C,D). Antennae (Figs. 11A, C, 12E) elongate, with three antennomeres, antennomere I partially sclerotized, sparsely setose, setae on membranous region very short; antennomere II $1.1 \times$ as long as I, fully sclerotized, sparsely setose, laterally flattened, apex ventrally with elliptical, flattened sensorium; antennomere III attached dorsally to antennomere $\mathrm{II}$, digitiform, $0.2 \times$ as long as antennomere II, with few fine setae subapically, one very short spiniform projection at apex. Epipharynx (Fig. 12C) with cross-shaped sclerite and two triangular striate plates; plates with anterior margin densely covered with fine setae and two orifices at lateral margins; hypopharynx (Fig. 12D) with anterior lobe triangular, densely setose; posterior part sclerotized, glabrous, with elongate concave projection. Mandibles (Fig. 12F) symmetrical, falcate, with a channel opening near apex, with ventral tuft of fine setae near channel opening; lateral margin at base covered with fine long setae; mesal
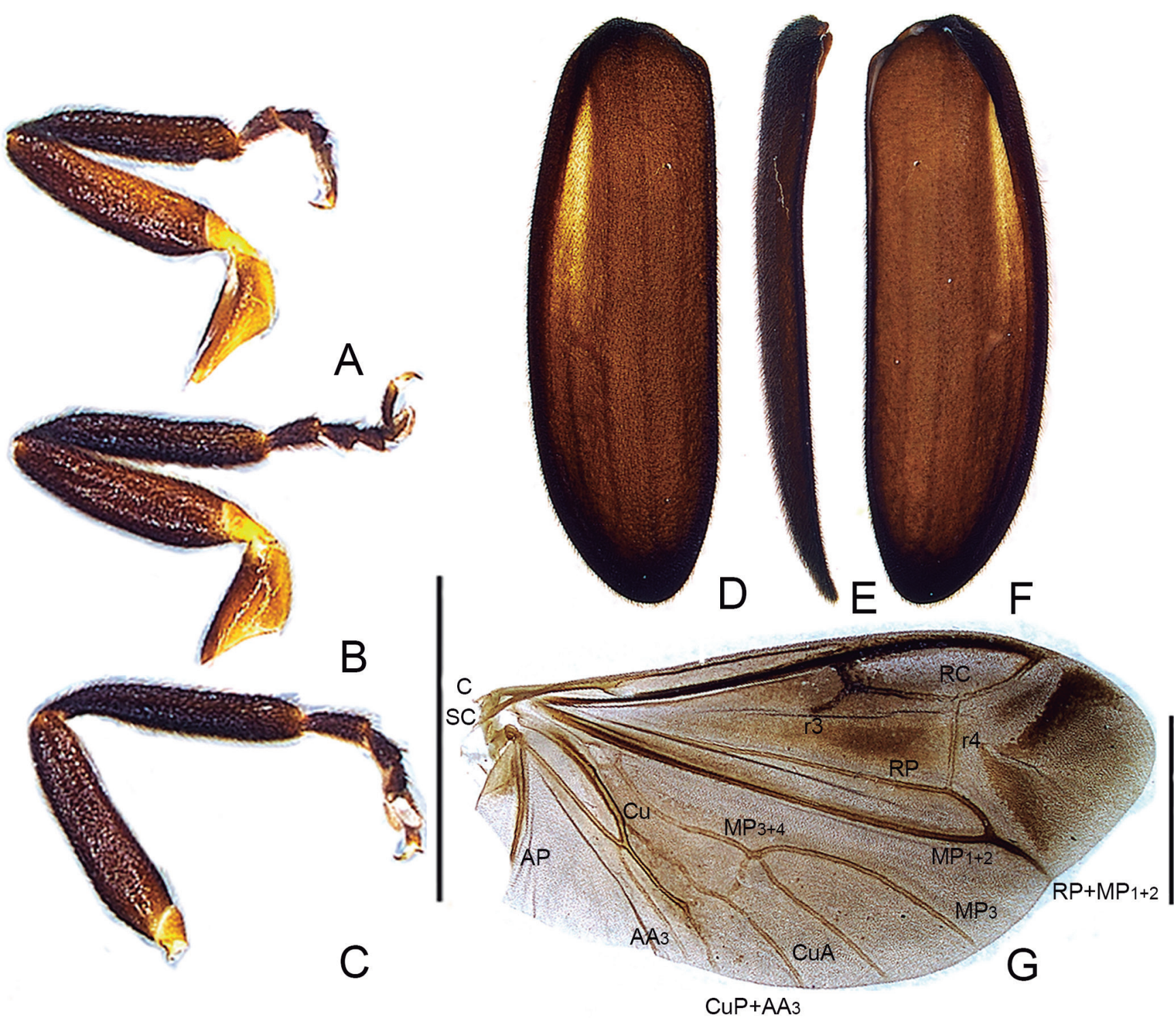

Figure 6. Psilocladus costae sp. nov. Thoracic appendages of adult male. (A-C) Left legs, ventral (anterior, middle and posterior, respectively); (D-F) elytron (dorsal, lateral and ventral); (G) left wing. Scale bar: $2 \mathrm{~mm}$. 


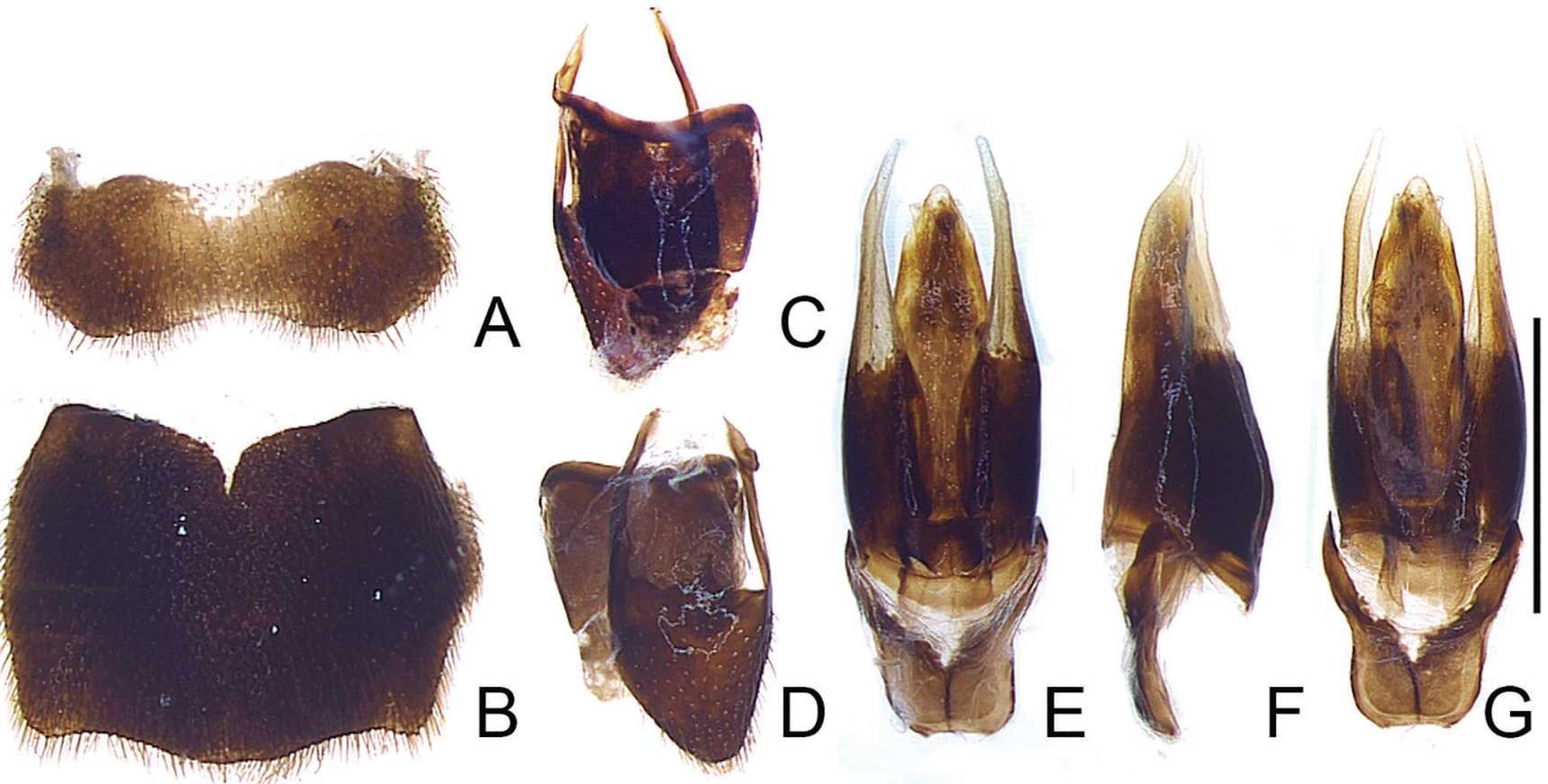

Figure 7. Psilocladus costae sp. nov. Terminal segments and aedeagus of male. (A) Sternum VIII; (B) pygidium; (C) syntergite; (D) sternum IX; (E-G) aedeagus (dorsal, lateral and ventral). Scale bar: $=1 \mathrm{~mm}$.

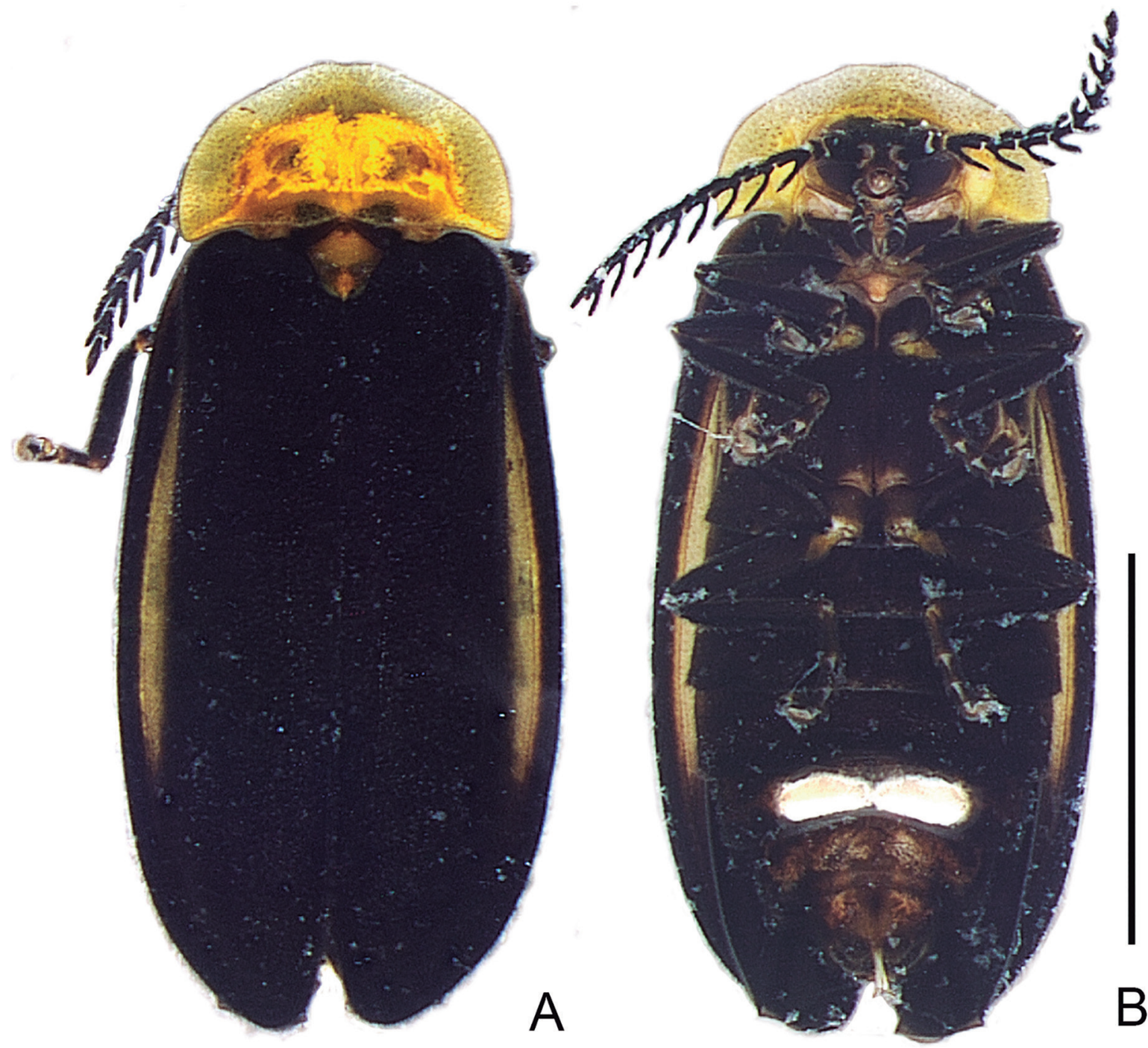

Figure 8. Psilocladus costae sp. nov. Adult female habitus. (A) Dorsal; (B) ventral. Scale bar: $=5 \mathrm{~mm}$. 


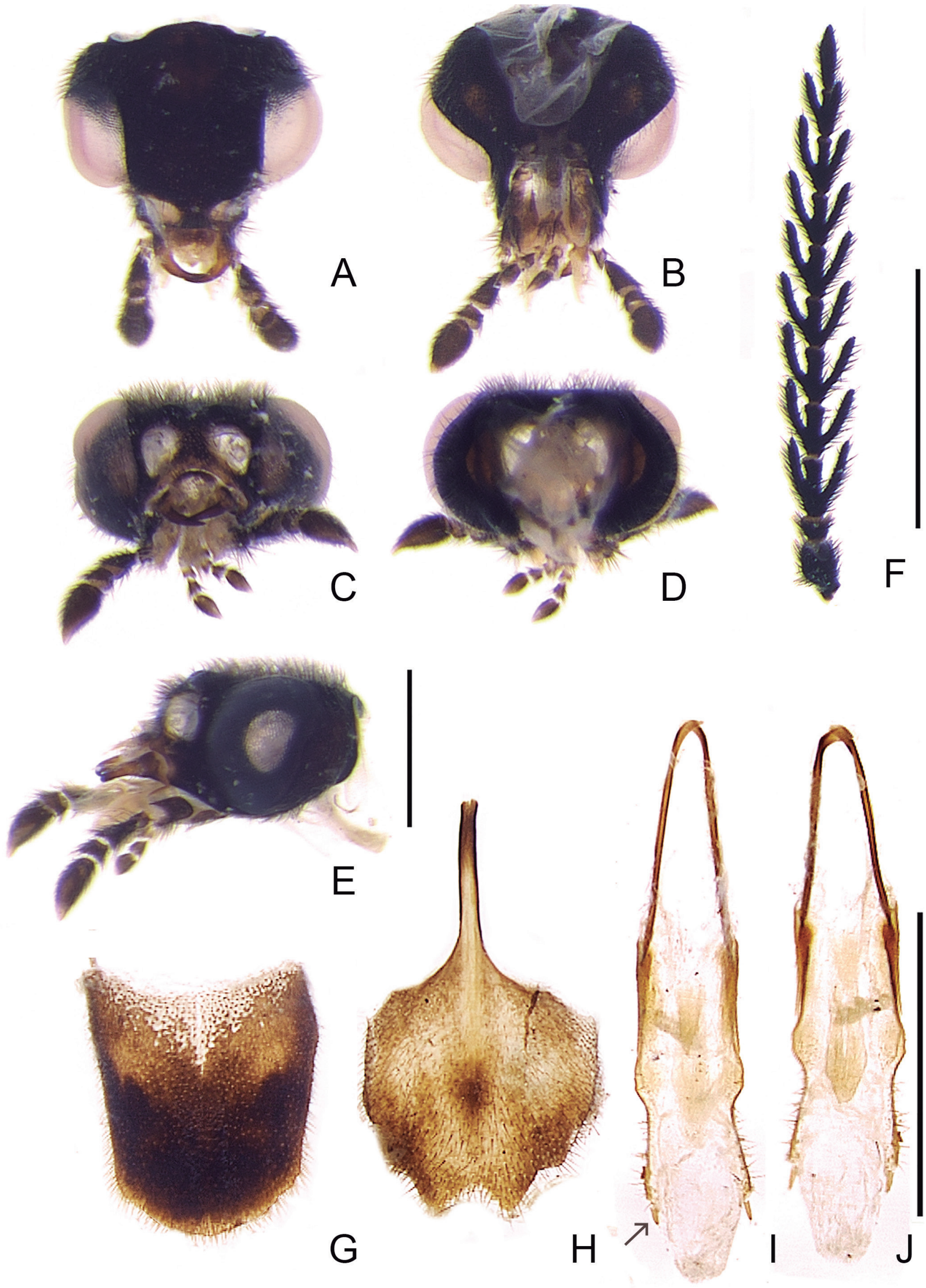

Figure 9. Psilocladus costae sp. nov. Adult female morphology. (A-E) Head; (A) dorsal; (B) ventral; (C) frontal; (D) occipital; (E) lateral; (F) left antenna (dorsal); (G) sternum VIII; (H) pygidium; (I, J) ovipositor (dorsal, ventral), arrow indicates stylus. Scale bars: A-E =1 mm; F-I $=2 \mathrm{~mm}$. 
margin at base with very short setae; row of sparse setae along channel dorsally; retinaculum well developed, forming a large and acute tooth; mesal membranous extension densely setose. Maxillolabial complex (Fig. 12B) separated from ventral head capsule by broad membrane; maxillae with cardo narrow, elongate, $0.5 \times$ as long as stripes, subparallel-sided; stipites elongate, with short membranous area on anterior margin, few fine setae irregularly distributed and a stout seta near base of galea; palpus 4-segmented, tapering toward apex with sparse fine setae and a stout seta on anterolateral margin of palpomere l; galea 2-articulated: basal palpomere triangular, as wide as long; apical palpomere digitiform, $5 \times$ longer than wide, with one stout long seta apically and few shorter setae subapically; lacinia consisting of densely pubescent structure connected to dorsomesal stipital edge; labium (Fig. 12B): prementum densely covered with moderately long setae, emarginated between palpi; palpus 2-articulated, apical palpomere as long as the basal one, strongly tapered apicad, with slot sensorium on outer side; mentum with anterior $1 / 3$ membranous; posterior $2 / 3$ sclerotized with pair of long setae at midlength; submentum and gula membranous. Post-occipital region as long as head, glabrous, with 3 elongate weakly sclerotized areas contiguous to anterior prothoracic collar.
Thorax (Fig. 10): tip of posterior angles of terga with long stout seta; pronotum semielliptical 1.3-1.6x wider than long, with posterior margin slightly emarginate, prosternum weakly sclerotized with short endocarinate rod between procoxae; anterior prothoracic collar membranous dorsally, strongly sclerotized on anterior $2 / 3$ ventrally; sclerotized region finely punctate/setose. Mesonotum as long as metanotum, both transverse with anterior angles rounded, posterior angles straight; mesonotum 3-3.3x wider than long; metanotum 3.3-3.6x wider than long; mesepisternum with a functional biforous spiracle on anterior corner; ventral surface of meso- and metathorax membranous medially, with sclerotized regions on pleurae laterally to coxae. Legs (Fig. 11D): coxa conical, strongly projected ventrad, partly strongly sclerotized, with fine long setae; trochanter with a few short stout setae; femur with sparse, evenly distributed spiniform setae and few short stout setae, and one long stout seta ventrally; tibiotarsus densely covered with spiniform setae; pretarsus with one seta on each side at base.

Abdomen (Figs. 10, 11E-F): Gradually narrowed posteriorly from segment III; terga I-VIII with well impressed sagittal ecdisial line, anterior angles rounded, posterior angles acute and strongly projected posteriad with stout long seta at tip; terga I-VI transversal, subequal in length;

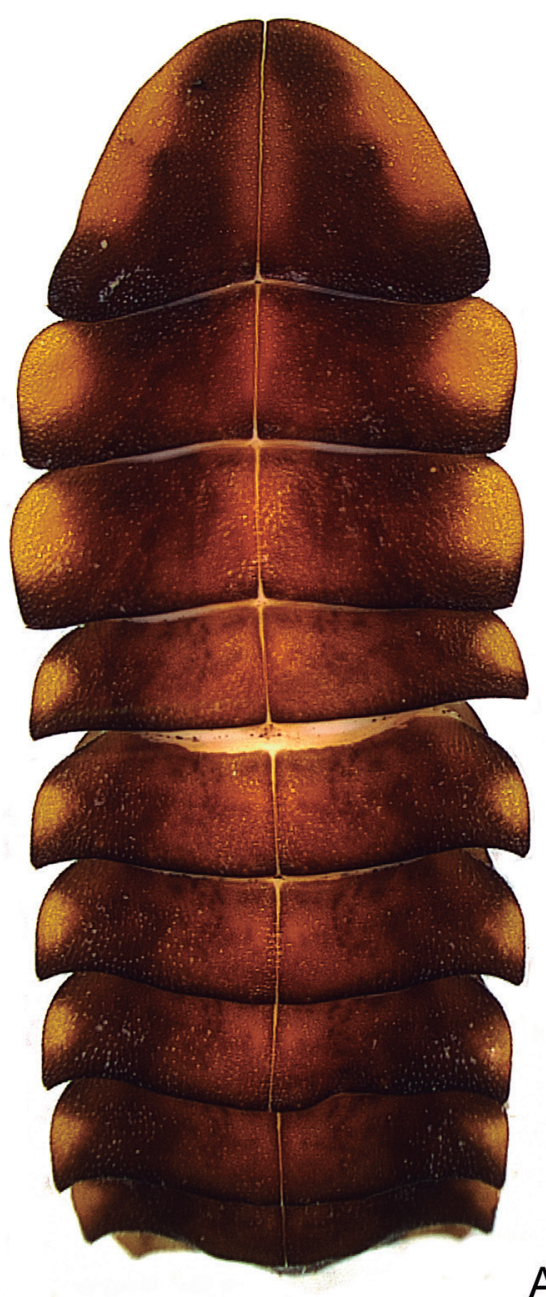

A

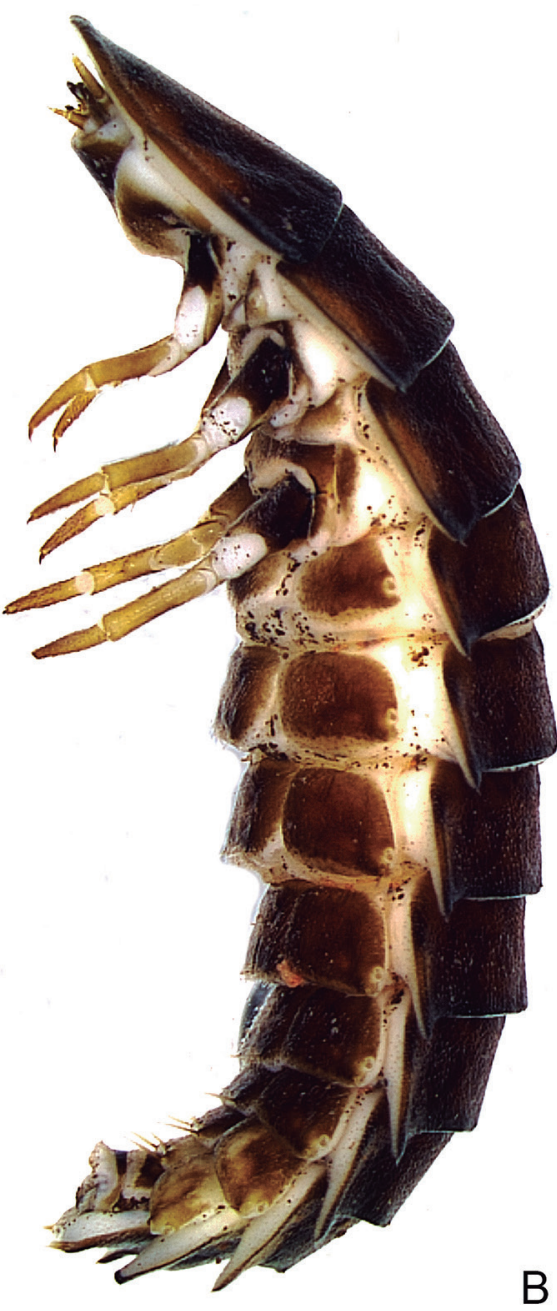

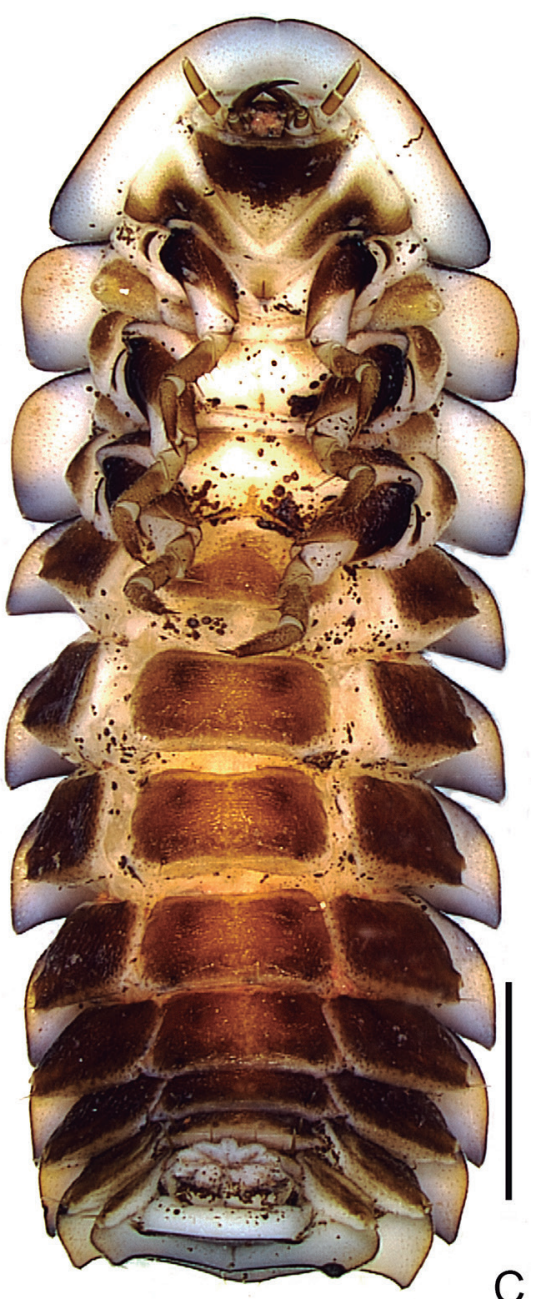

Figure 10. Psilocladus costae sp. nov. Mature larval habitus. (A) Dorsal; (B) lateral; (C) ventral. Scale bar: $=2 \mathrm{~mm}$. 
tergum I about $4.3 \times$ wider than long, $\mathrm{VI} 3.7 \times$ wider than long; tergum VIII $1.5 \times$ wider than VII, with posterior margin broadly emarginate; tergum IX as long as wide, lateral margins subparallel, posterior angles weakly projected with tuft of foliaceus setae at tip, posterior margin slightly rounded. Sternites I-IX sclerotized, with two pairs of parasagittal very short stout setae (at midlength and posterior margin) and long stout seta at posterior angles; sternites VI-VIII with additional pair of stout seta near lateral margins; stout setae increasing in length from sternites I-IX; laterotergites I-VIII 0.6-0.8X as large as respective sternites, sclerotized, posterior corners projected, with 2 prominences; anterior prominence with biforous spiracle, posterior prominence with a stout long seta; sternite VIII with pair of light organ on anterior corners. Segment X (Figs. 10B-C) attached under segment IX, tergum broadly conate or fused to sternum IX; sternum glabrous, most part sclerotized, except by subapical membranous transverse area; pygopod present.
Pupa (Fig. 13): Total length ca. $7.0 \mathrm{~mm}$, adecticous, exarate, white. Pronotum semicircular, anterior and lateral margins densely setose, setae long and stout. Dorsal surface with short setae. Posterior margin with posterior angles rounded, projected posteriad, median region straight. Mesothorax with a pair of reniform spiracles on posterior half of pleurite. Metanotum $1.1 \times$ as long as mesonotum, with a pair of long setae on posterior third. Abdominal terga I-VIII transverse, with posterior angles acute, strongly projected posteriad; lateral margins densely setose; setae long stout; tergite IX subquadrate with posterior angles weakly projected, with tuft of stout setae. Pair of light organ on sterna VI and VII (Fig. 14B), inconspicuous in alcohol-preserved specimen. Abdominal spiracles located ventrally on posterior angles of pleurae on segments I-VIII.

Remarks: Psilocladus costae sp. nov. is the first Psilocladinae species to have their immature stages de-
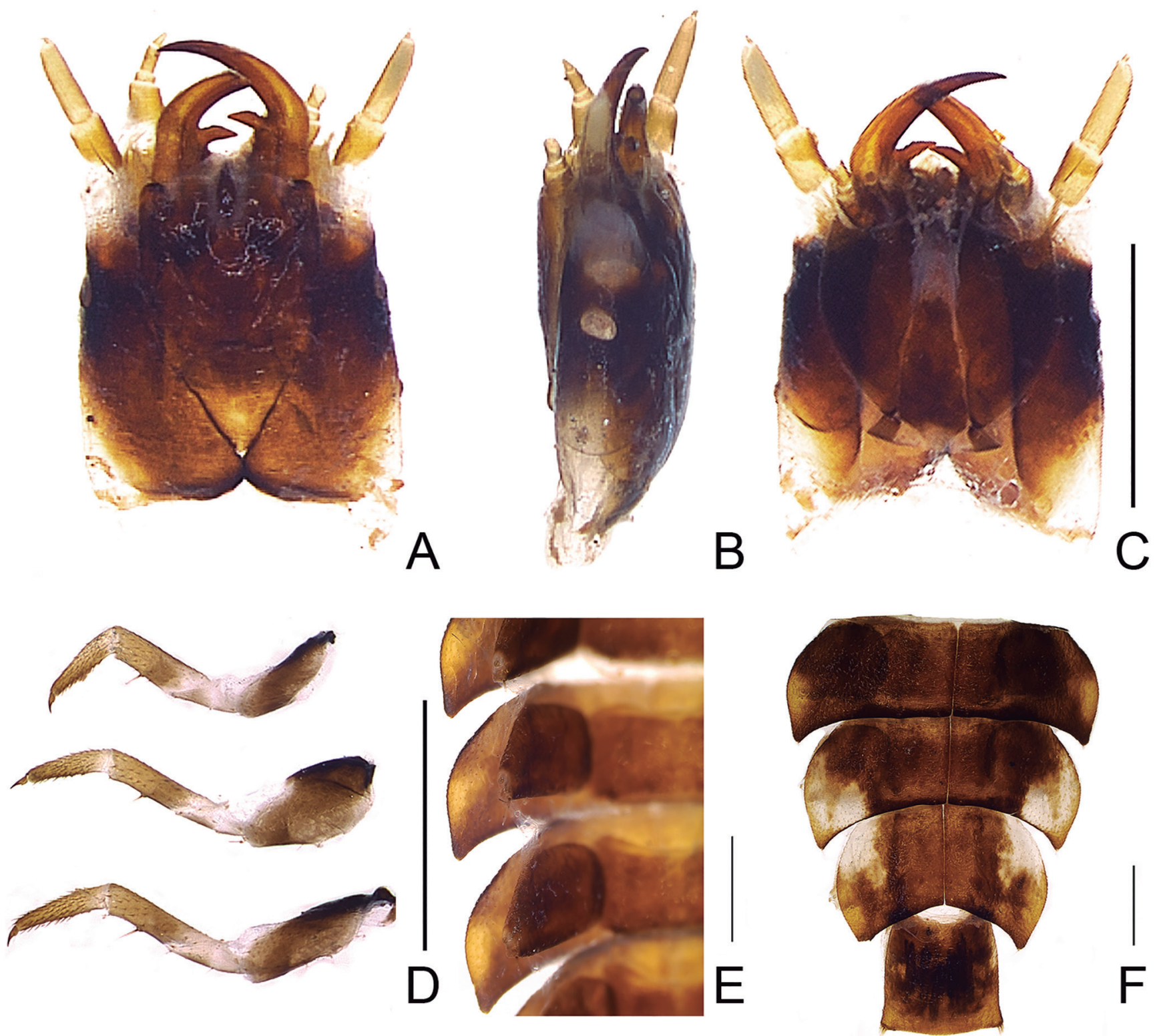

Figure 11. Psilocladus costae sp. nov. Larval morphology. (A-C) Head (dorsal, lateral, ventral); (D) right anterior, middle and posterior legs (from top to bottom, ventral); (E) left laterotergites VI-VII; (F) abdominal terga VI-IX. Scale bars: A-C, E, F=1 mm; D = $2 \mathrm{~mm}$. 
scribed. The larva of this species is more similar to those of Photurinae species: Photuris fulvipes Curtis (Rosa, 2007) and an unidentified species of Bicellonycha Motschulsky (Costa et al., 1988). Those species share the oblong body (with semioval pronotum, widest at metathorax and gradually decreasing in width from abdominal segment III) (Fig. 10A), head with frontal arms well impressed posteriorly and divergent anteriad (V- or U-shaped), clypeolabrum with a median tooth darkly sclerotized, sensorium on second antennomere flattened (Figs. 11A, 12A, E), pretarsus with one basal seta on each side, and presence of localized stout setae on thorax and abdomen (Fig. 11E). They differ in the density and distributional pattern of the stout setae on thoracic and abdominal segments. Stout setae are sparser in Psilocladus costae sp. nov. and in Photuris femoralis, but in P. costae sp. nov. they are shorter and absent on median part of thoracic and abdominal terga. Larvae of $P$. costae sp. nov. also differ from both $P$. femoralis and Bycellonycha sp. larvae by having mandible sparsely setose and abruptly curved on apical half (Fig. 12F), hypopharynx with single anterior lobe and posterior part elongate (Fig. 12D), vitreous spots on terga VII and VIII, and tergite IX somewhat quadrate (Fig. 11F) (in Photurinae larvae, mandible is densely setose and gradually curved, the hypopharynx is bilobed with posterior part short, vitreous spots are absent, and the tergite IX is semioval). The pupa of $P$. costae sp. nov. is also more similar to the pupae of the photurine species than to pupae of other Neotropical species belonging to the genera Aspisoma Laporte, Lucio Laporte, Cratomorphus Motschulsky and Pyractonema Olivier. Photurinae and $P$. costae sp. nov. pupae share the presence of dense, long and stout setae on pronotal margins and posterior angles of abdominal terga (Fig. 13). Psilocladus costae sp. nov. pupa differs by having photophores on abdominal segments VI and VII (Fig. 14B), whereas photurine pupae have only one pair of photophores on segment VIII.

Etymology: The specific epithet is in honor to Professor Dr. Cleide Costa who dedicated many studies to immature beetles, especially Elateroidea. Singular genitive, feminine.

Field and laboratory observations: We collected 49 larvae inside fallen epiphytic bromeliads. Few larvae were collected outside of bromeliads during the night when they were localized by their very bright bioluminescence (Fig. 14A). Those larvae were identified by comparison with the bromeliad larvae. Of the 61 fallen bromeliads investigated, 26 had larvae of Psilocladus costae sp. nov., the majority of which found in the innermost leaves of the bromeliad rosette. The number of larvae inside each bromeliad ranged from one to five, but in most of them ( $n=16$ ) we found only one larva. They were found inside bromeliads throughout the year (22 larvae from April to August and 21 larvae from September to March), whilst active glowing larvae outside of bromeliads were found in the beginning of the rainy season (six larvae in October and November). At night larvae were found by their intense glow near bromeliad tanks, above leaf blades (Fig. 14A) and on trunks and branches near bromeliads fixed on trees. Larvae emit green light, easily seen from above through the vitreous spots on tergum VIII when the larvae are stretched, as well as through
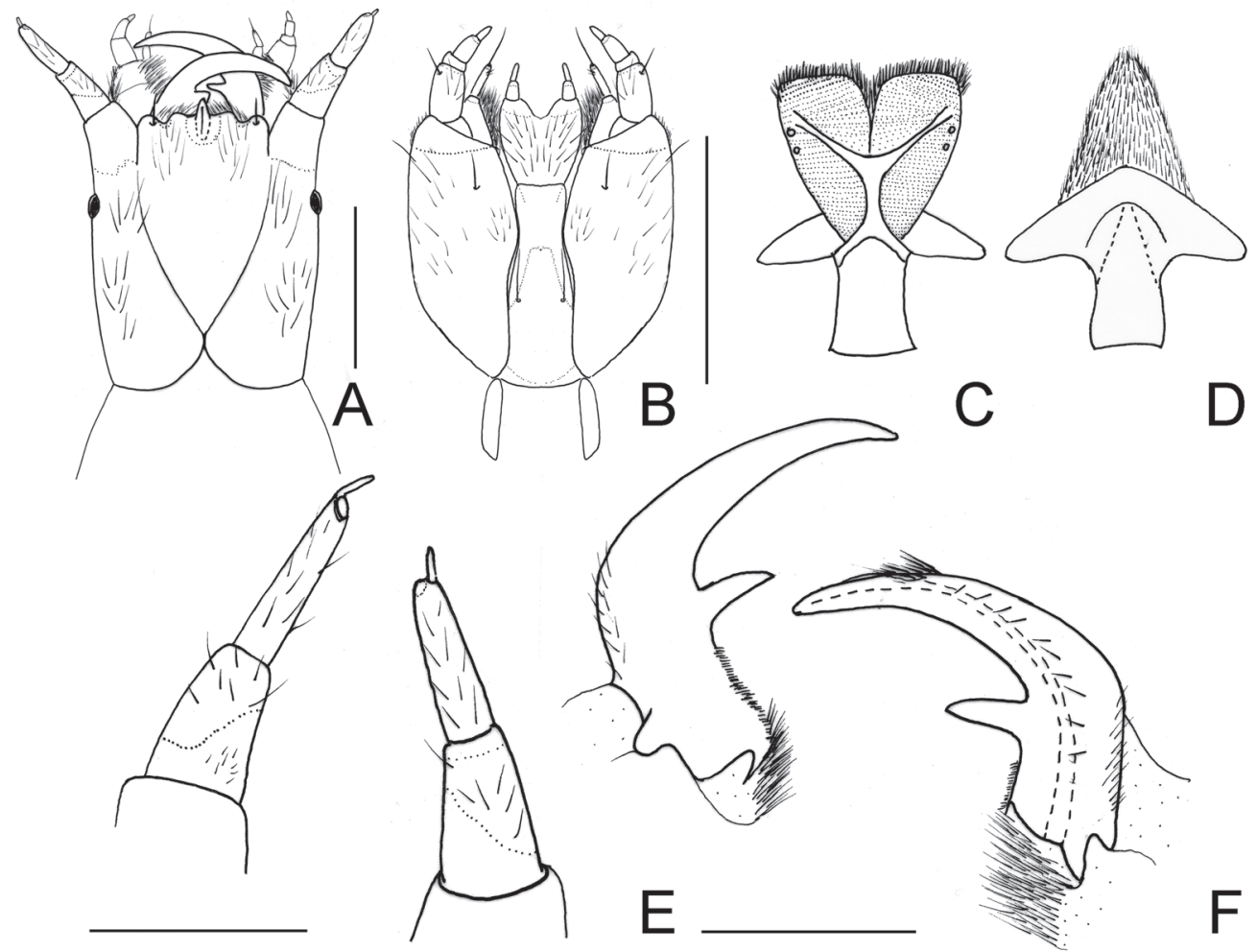

Figure 12. Psilocladus costae sp. nov. Larval head morphology. (A) Head, dorsal; (B) maxillolabial complex, ventral; (C) epipharynx; (D) hypopharynx; (E) left antenna (ventral, dorsal); (F) mandible (ventral, dorsal). Scale bars: $A, B=1 \mathrm{~mm} ; C, D=0.25 \mathrm{~mm} ; E, F=0.5 \mathrm{~mm}$. 

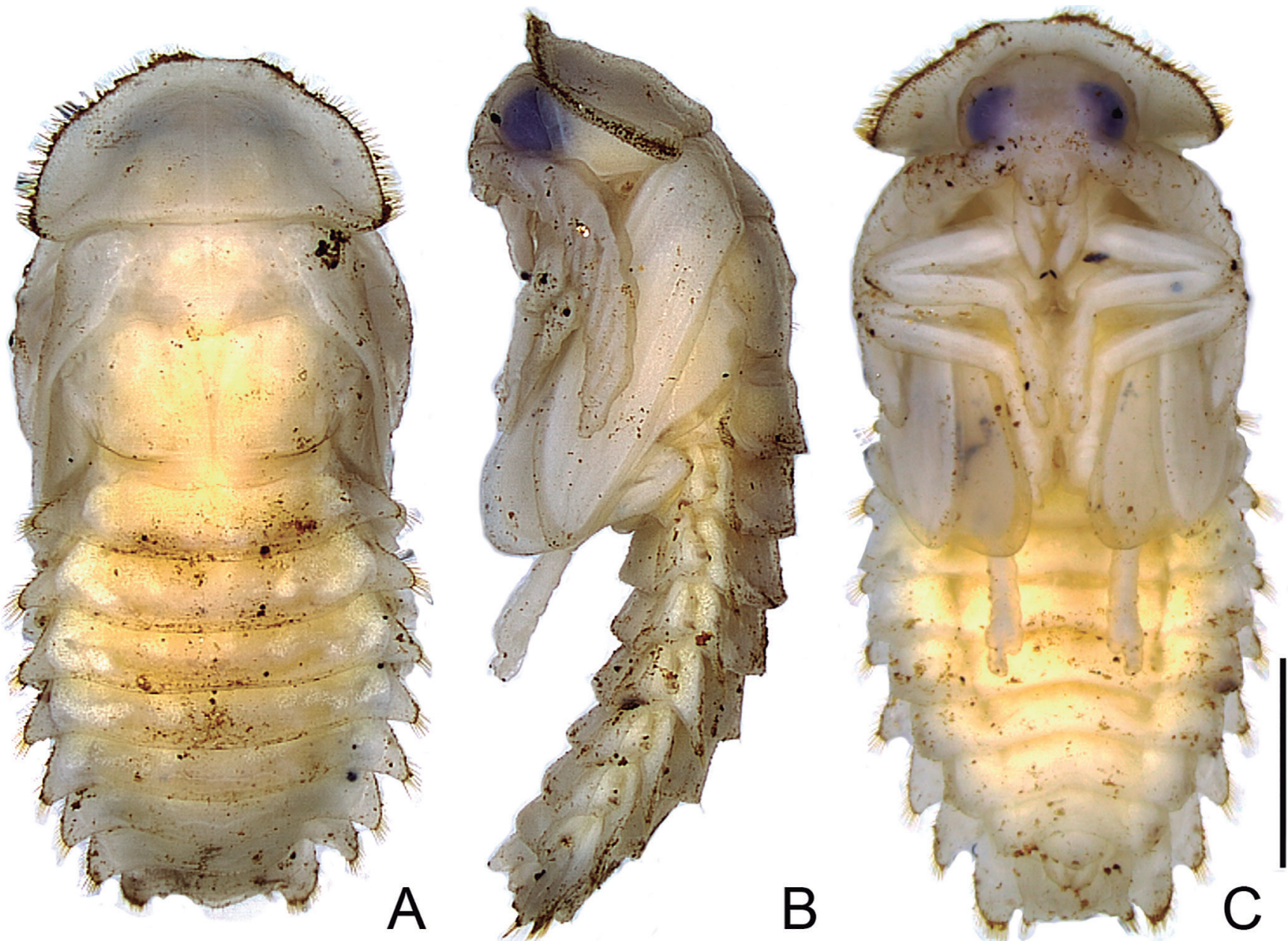

Figure 13. Psilocladus costae sp. nov. Pupal habitus. (A) Dorsal; (B) lateral; (C) ventral. Scale bar: $=2 \mathrm{~mm}$.

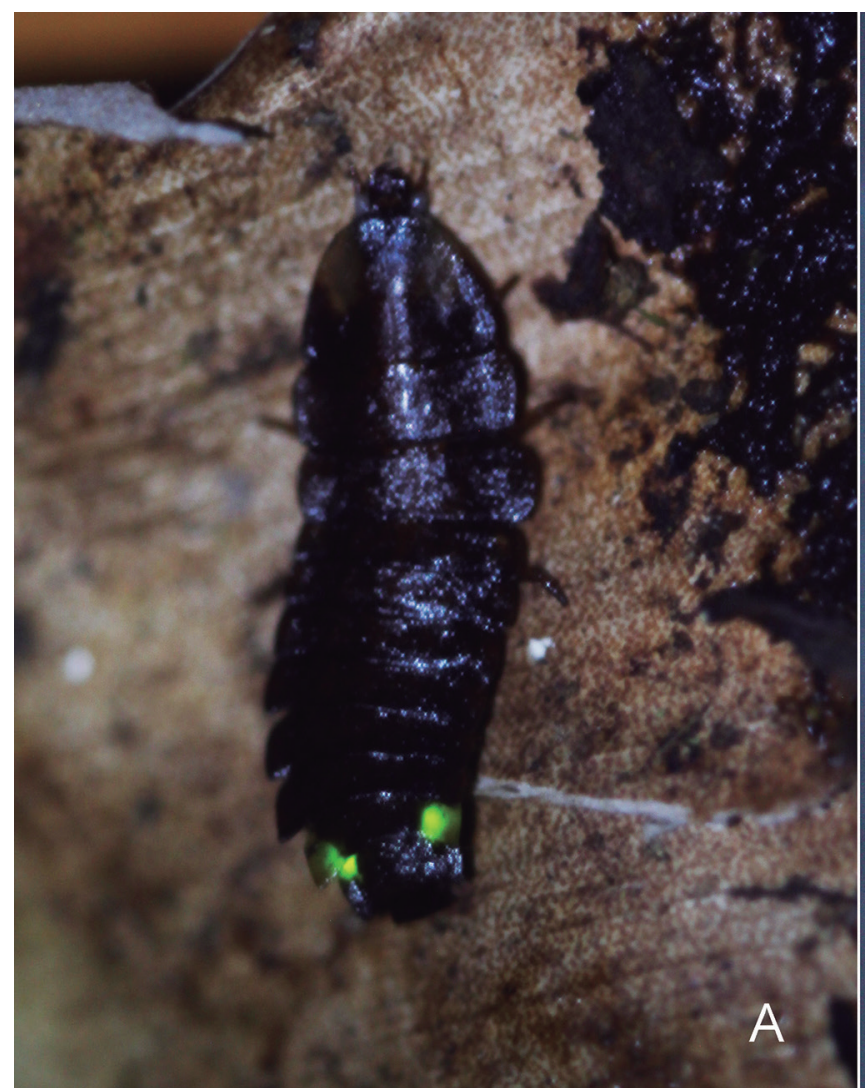

Figure 14. Psilocladus costae sp. nov. Immature bioluminescence. (A) Larva (dorsal); (B) pupa (ventral). Length: larva = $18 \mathrm{~mm} ; \mathrm{pupa}=7 \mathrm{~mm}$. 
vitreous spots on tergum VII, that covers the VIII when larvae shrink. In the lab, larvae preyed on termites and scirtid larvae. Mortality was very high and only two firefly larvae molted into pupa and adult, therefore we could not determine the number of larval instars. Larval length ranged from 9 to $22 \mathrm{~mm}$ and the larvae which molted into pupa and adult were ca. $15 \mathrm{~mm}$ long, therefore we infer that mature larva may be $15-22 \mathrm{~mm}$ long. A few larvae possibly died due to acari infestation, but the causes of overall mortality were not known. Adults were observed on wet and dark nights in December and January. They flew at about 10 meters height whilst glowing green continuously, rarely below 5 meters, yet 10 specimens could be collected on the grass and on leaf blades of bromeliads fixed lower on the trees. The flying adults concentrated in areas with higher density of canopy bromeliads (Figs. 1B, C).

\section{Concluding remarks}

\section{Bromeliad-inhabiting fireflies}

Bromeliad tanks can be thought of as complex ecosystems which house several species, including beetles. Although the study of bromeliad-inhabiting beetles in South America dates back to 1900 (Ohaus, 1900), recently there has been renewed interest (e.g., Albertoni et al., 2016; Biffi \& Rosa, 2019). Because bromeliads provide important environmental needs of firefly larvae, viz. food (gastropods and other soft-bodied invertebrates) and moisture (in the bromeliad tank), they are obviously well-suited spots for fireflies. Our study is the first detailed report of fireflies living in bromeliad tanks, as far as we are aware. Other studies in South America have indeed found firefly larvae in bromeliad tanks, but rather focusing on the plant's ecology, that is, not on the insects themselves, and the identity of the species were never addressed (e.g., Givnish et al., 1984; Aguilera-Arango et al., 2011; Rogy et al., 2019).

Fireflies are usually found in mesic and hydric environments, arguably because: (i) their soft carapaces make them relatively more subject to water loss, which is also seen in other soft-bodied beetles (e.g., Lycidae, see Bocak et al., 2008), in comparison with most other beetles; and (ii) they usually prey on gastropods, earthworms and other soft-bodied animals, also usually restricted to mesic and hydric environments. Bromeliads are well-suited spots for fireflies, damp and packed with soft-bodied invertebrates. Thus, future studies addressing the macroinvertebrate faunas in bromeliads are likely to find fireflies.

We found no obvious morphological adaptations to an aquatic lifestyle in Psilocladus costae sp. nov. However, it is reasonable to assume that $P$. costae sp. nov. is semi-aquatic, as larvae tolerate some level of water submersion, as the majority of them were found at basal older leaves, which are constantly submerged in water. Another evidence that larval $P$. costae sp. nov. withstands some time under water is that under lab conditions, it readily preyed on aquatic larvae of scirtid beetles, which were highly abundant in the bromeliad tank. It is yet un- known whether or not this firefly species feed on scirtid beetles under natural conditions. The presence of larvae outside bromeliads during night suggests that they migrate out of bromeliad through the water and possibly feed on preys that are attracted by their intense glow.

\section{ACKNOWLEDGMENTS}

We thank Tânia A. Barbosa and Michael Ladenthin for their help in the laboratory and field work, respectively, Lynn Faust for critical comments and review, and Chico Mendes Institute (ICMBio) for the research permit (SISBio 61146). This research was partially supported by Fundação de Amparo à Pesquisa do Estado do Rio de Janeiro (FAPERJ 101.476/2010) and Instituto Nacional de Ciência e Tecnologia dos Hymenoptera Parasitoides da Região Sudeste Brasileira (through Conselho Nacional de Desenvolvimento Científico e Tecnológico, Coordenação de Aperfeiçoamento de Pessoal de Nível Superior [CAPES] and Fundação de Amparo à Pesquisa do Estado de São Paulo) and PVE (via CNPq 400261/2014-6), which provided infrastructure and equipments (e.g., stereomicroscope) to S.V. We thank A. Taghavian for granting access to L.F.L.S. to MNHN Lampyridae holdings.

\section{REFERENCES}

Aguilera-Arango, A.; Isaza Guzmán, G. \& González, R. 2011. Diversidad y abundancia de la artropofauna en bromelias de bosques de manglar de la bahía de Buenaventura (Valle, Colombia). Boletín del Museo de Entomología de la Universidad del Valle, 12(1): 1-11.

Albertoni, F.F.; Steiner, J. \& Zillikens, A. 2016. The associated beetle fauna of Hohenbergia augusta and Vriesea friburgensis Bromeliaceae in southern Brazil. Journal of Natural History, 50: 2917-2939.

Archangelsky, M. 2004. Higher-level phylogeny of Hydrophilinae (Coleoptera: Hydrophilidae) based on larval, pupal and adult characters. Systematic Entomology, 29(2): 188-214. D0I

Archangelsky, M. 2010. Larval and pupal morphology of Pyractonema nigripennis Solier (Coleoptera: Lampyridae: Photinini) and comparative notes with other Photinini larvae. Zootaxa, 2601: 37-44.

Ballantyne, L.A.; Lambkin, C.L.; Ho, J.Z.; Jusoh, W.F.A.; Nada, B.; Nak-Eiam, S.; Thancharoen, A.; Wattanachaiyingcharoen, W. \& Yiu, V. 2019. The Luciolinae of SE Asia and the Australopacific region: a revisionary checklist (Coleoptera: Lampyridae) including description of three new genera and 13 new species. Zootaxa, 4687(1): 1-174.

Beutel, R.G. 1995. Phylogenetic analysis of Elateriformia (Coleoptera: Polyphaga) based on larval characters. Journal of Zoological Systematics and Evolutionary Research, 33: 145-171. DOI

Biffi, G. \& Rosa, S.P. 2019. Morphology of bromeliad-associated immature stages of Daiphron bipartitus and its adults confirms the non-monophyly of the genus (Coleoptera: Cantharidae). Acta Entomologica Musei Nationalis Pragae, 59(1): 139-150. D0I

Bocak, L.; Bocakova, M.; Hunt, T. \& Vogler, A.P. 2008. Multiple ancient origins of neoteny in Lycidae (Coleoptera): consequences for ecology and macroevolution. Proceedings of the Royal Society of London B, 275: 2015-2023. D0I

Branham, M.A. 2010. Lampyridae. In: Leschen, R.A.B.; Beutel, R.G. \& Lawrence, J.F. (Eds.). Coleoptera, Beetles. Vol. 2: Morphology and 
systematics (Elateroidea, Bostrichiformia, Cucujiformia partim). Berlin, Walter de Gruyter. p. 141-147. (Handbook of Zoology, Arthropoda: Insecta). DOI

Campos, S.V.N.; Silveira, L.F.L. \& Mermudes, J.R.M. 2018. Systematic review of the giant firefly Cratomorphus cossyphinus: sexual dimorphism, immature stages and geographic range. Annales Zoologici, 68(1): 57-84. $\underline{\mathrm{DOl}}$

Chen, L.; Shi, X.; Li, M.; Hu, J.; Sun, S.; Su, B. \& Song, Y. 2015. Bioinspired photonic structures by the reflector layer of firefly lantern for highly efficient chemiluminescence. Scientific reports, 5(12965): 1-7. DOI

Costa, C. 2000. Estado de conocimiento de los Coleoptera neotropicales. In: Martín-Piera, F.; Morrone, J.J. \& Melic, A. (Eds.). Hacia un proyecto CYTED para el inventario y estimación de la diversidad entomológica en iberoamérica: Pribes 2000. Zaragoza, Sociedad Entomológica Aragonesa. v. 1, p. 99-114.

Costa, C.; Vanin, S.A. \& Casari-Chen, S.A. 1988. Larvas de Coleoptera do Brasil. São Paulo. Museu de Zoologia, Universidade de São Paulo, Fapesp. 262p.; 165 estampas. DOI

Faust, L.F. 2010. Natural history and flash repertoire of the synchronous firefly Photinus carolinus (Coleoptera: Lampyridae) in the great Smoky Mountains National Park. Florida Entomologist, 93(2): 208-217. D0I

Faust, L.F. 2017. Fireflies, Glow-worms, and lightning bugs: identification and natural history of the Fireflies of the Eastern and Central United States and Canada. Georgia, University of Georgia Press. 376p. (Wormsloe Foundation Nature Book Ser.)

Fu, X. \& Meyer-Rochow, V.B. 2013. Larvae of the firefly Pyrocoelia pectoralis (Coleoptera: Lampyridae) as possible biological agents to control the land snail Bradybaena ravida. Biological control, 65(2): 176-183. D0I

Givnish, T.J.; Burkhardt, E.L.; Happel, R.E. \& Weintraub, J.D. 1984. Carnivory in the Bromeliad Brocchinia reducta, with a Cost/Benefit Model for the General Restriction of Carnivorous Plants to Sunny, Moist, Nutrient-Poor Habitats. The American Naturalist, 124(4): 479-497. DOI

Instituto Nacional de Meteorologia (INMET). 2019. Gráficos Climatológicos 1931-1960. Available at: http://www.inmet.gov.br/portal/index. php?r=clima/graficosClimaticos. Access in: /12/12/2019.
Jeong, G.H.; Roh, Y.H. \& Yhang, W.J. 2005. Visitors' perceptions to ecotourism goals and satisfaction: The case of Muju Firefly Festival. Journal of Environmental Science International, 14(4): 373-377. D0I

Martin, G.J.; Stanger-Hall, K.F.; Branham, M.A.; Da Silveira, L.F.; Lower, S.E.; Hall, D.W.; Li, X.Y.; Lemmon, A.R.; Moriarty Lemmon, E. \& Bybee, S.M. 2019. Higher-Level Phylogeny and Reclassification of Lampyridae (Coleoptera: Elateroidea). Insect Systematics and Diversity, 3(6): ixz024. DOI

McDermott, F.A. 1964. The Taxonomy of the Lampyridae (Coleoptera). Transactions of the American Entomological Society, 90(1): 1-72.

McDermott, F.A. 1966. Lampyridae. In: Steel, W.0. (Ed.). Coleopterorum Catalogus Supplementa. Pars 9. 2.ed. The Hague, W. Junk. 149p.

Ohaus, F. 1900. Bericht über eine entomologische Reise nach Centralbrasilien. Stettiner Entomologische Zeitung, 61: 164-191.

Rogy, P.; Hammil, E. \& Srivastava, D.S. 2019. Complex indirect effects of epiphytic bromeliads on the invertebrate food webs of their support tree. Biotropica, 51(4): 549-561. D01

Rosa, S.P. 2007. Description of Photuris fulvipes (Blanchard) immatures (Coleoptera, Lampyridae, Photurinae) and bionomic aspects under laboratory conditions. Revista Brasileira de Entomologia, 51(2): 125-130. DOI

Silveira, L.F.L. \& Mermudes, J.R.M. 2014. Systematic review of the firefly genus Amydetes Illiger, 1807 (Coleoptera: Lampyridae), with description of 13 new species. Zootaxa, 3765(3): 201-248. D01

Souto, P.M.; Campello, L.; Khattar, G.; Mermudes, J.R.M.; Monteiro, R. \& Silveira, L.F.L. 2019. How to design a predatory firefly? Lessons from the Photurinae (Coleoptera: Lampyridae). Zoologischer Anzeiger, 278: 1-13. DOI

Viviani, V.R. 1989. Descrição dos estágios imaturos e dados biológicos de Aspisoma sp. (Coleoptera: Lampyridae). Revista Brasileira de Entomologia, 33: 359-366. D0I

Viviani, V.R.; Rosa, S.P. \& Martins, M.A. 2012. Aspisoma lineatum (Gyllenhal) (Coleoptera: Lampyridae) Firefly: Description of the Immatures, Biological, and Ecological Aspects. Neotropical Entomology, 41(2): 89-94. DOI 